\title{
ARCHIVING THE AVANT-GARDE
}

EVERY SPECIAL COLLECTION has a distinct personality that is a combination of its contents and the people who work with it. Such is the case with the Franklin Furnace Archive. Everything in Franklin Furnace is a special collection. The institution is governed by a type of reverse Darwinism best described as "survival of everything." Right now the archive is storing all the virtual material that it produces and presents on the Internet. Not long ago, any physical material that walked through the door was given an accession number and stuffed into a Hollinger record storage box. Eventually, all those boxes became the largest public collection of artists' books in the United States. The book collection was acquired by the Museum of Modern Art in 1993. The current Franklin Furnace Archive collection consists of every event of performance art and installation art that it ever produced.

The drive to archive and collect is obviously a primal one. For some people, it's right up there with sex, TV, and Elvis (three popular categories in the archive). Many of those people also are Franklin Furnace artists, employees, and interns. At one point, the primal drive became so strong that an exhibition (The Pack Rat Show, 1983) of their private collections was organized. Some of the collections on display included: "found knots from around the world," "umbrella handles," "snow shakies," and "pink things for girls."

Sometimes, to members of the staff, life itself begins to take on aspects of one big special collection. The founder/director literally lived inside 
the Franklin Furnace artist book collection in the early days until its expansion forced her out. Her ten-year-old son continues in the family tradition with a large — and getting larger-basketball card collection, which is, of course, housed in archival sleeves. The administrative director teaches collecting in the New York City school system. He has created many collections but is best known for a Chinese menu exhibition ("A Million Menus," 1991). The archivist, with Franklin Furnace since 1980, limits his collecting to several hundred shot glasses, prominently displayed, and useful for serving refreshments to guests.

Franklin Furnace advertises on its Web site that it is "on a mission from God to make the world safe for avant-garde art." This cannot be done by staff members alone. The archive has lived up to its reputation by using a panel of artists to choose what is presented. No censorship is allowed. Under this democratic system, lint circles and used chewing gum (Betty Ruth Curtiss posthumous retrospective, 1987) reside amicably in the archive with a roomful of decorated dildos titled "The Lesbian Museum" (Nicole Eisenman and Chris Martin, 1992). Frank Moore, the paraplegic, self-proclaimed sex symbol, conducts his performance naked, in a room filled with naked people including some members of the audience ("Intimate Cave," 1987). Everything is archived, excluding the gum and the dildos. All the installation photographs and slides, videos, correspondence, press articles, etc., are placed in floor-to-ceiling arrangements of perfectly aligned gray document cases.

Special collections are serious work, and serious work does not go unnoticed by the U.S. government. In the past, certain politicians have adopted an anti-Franklin Furnace stance for political gain. Tax dollars have been spent to prevent the dissemination of our alleged "obscene art." The whole story can be pieced together from within the archive under "Helms, Jesse" (Senator, North Carolina) and "Finley, Karen" (performance artist) ("A Woman's Life Isn't Worth Much," 1990). This type of political activity was the beginning of the eventual elimination 
of the individual artists grants awarded by the National Endowment for the Arts. The indirect effect on Franklin Furnace was downsizing, relocation, and elimination of installations and live performance. Presently, we produce a program of contemporary performance art on the Internet.

At this point, the archive is almost like an interactive artwork involving its own history, the artists who create the material, society, and the staff members who coordinate it all. Special collections will define themselves if one is sensitive to the process and provides gentle guidance. Franklin Furnace holds to this view and nourishes its special collections through a mixture of presentation and preservation, simultaneously presenting the new and preserving the old.

Prior to 1997 (before the downsizing), all archive materials were firsthand documentation of events. Materials such as slides, photographs, and videos only mimic the experience of live events and provide a secondhand experience. After 1997, when Franklin Furnace began using the Internet as a performance art vehicle, the lines started to blur. Suddenly, material stored in the archive functioned as firsthand experience (not unlike artists' books). Viewing an artist-produced CD-ROM from the archive is no different from viewing the original netcast. Does this trend signal the end of special collections?

To keep special collections special it is best to be autonomous, and allow for adaptability and flexibility in an age of rapid change. For Franklin Furnace, this means that all materials are not treated the same. Video and slide documentation remain in use. Digitization of analog material will enhance, but not replace, the originals. Digital materials will remain digital and relational databases will unify all the material for searching. In the era of the "information superhighway," Franklin Furnace feels pressured to make as much information available to as many people as possible. This is best accomplished by making these databases accessible 
on the Internet, even if the Internet is a compromised representation of the actual collection.

As performance artwork becomes increasingly digital, it will be less compromised by the Internet. Digital artwork, however, unfailingly produces physical items such as CD-ROMs, handwritten notes, press articles in magazines, and phone message pads. The experience at Franklin Furnace is that the production of digital artwork creates enough raw material to satisfy any special collection. As long as humans retain a physical presence, there will be a desire to collect physical stuff. It's the calling of the special people in special collections to recognize and collect it. 